\title{
Reflections on the History of Computer Education in Schools in Victoria
}

\author{
Arthur Tatnall $^{1}$ and Bill Davey ${ }^{2}$ \\ ${ }^{1}$ School of Management and Information Systems, Victoria University, \\ Melbourne, Australia \\ Arthur. Tatnallevu.edu.au \\ ${ }^{2}$ School of Business IT and Logistics, RMIT University, \\ Melbourne, Australia \\ Bill. Davey@rmit.edu.au
}

\begin{abstract}
This paper traces the introduction of computing into schools in the Australian State of Victoria. Told from the point of view of two active participants, the story exposes a number of themes that resonate with experiences in other countries. From its beginnings in the 1970s on borrowed or shared minicomputers and the use of punched cards for teaching programming in conjunction with facilities at local universities, progress in the 1980s was rapid after the advent of the relatively low cost microcomputer. This article tells the story of how computer education developed in Victoria in the 1970s and 1980s, leaving discussion of more recent history for another time.
\end{abstract}

Keywords: Computer Education, Schools, Victoria, Microcomputers, Curriculum, Professional Development.

\section{Introduction}

Australia is an interesting country in which to study the development of computing. One of the very first computers (CSIRAC) was developed by the Commonwealth Science and Industry Research Organisation (CSIRO) and exists as the only remaining complete first generation computer today. (It is on display at Museum Victoria in Melbourne.) Australia is also well known for early adoption of new technologies and their rapid incorporation into the education system. In the State of Victoria in 1974 Monash University provided the specially created MONECS system to allow schools to teach programming using mark sense-cards. Victoria embraced computers from a very early stage and so this story relates some of the history of the introduction of computers into education in an environment where no global exemplars existed. The story is clearly seen through the eyes of two people who were present at the centre of developments and it is their reflection that flavours the choice of reported events. It involves many different human and non-human actors (Callon 1986; Latour 1991; Latour 1996). The human actors are readily apparent, but it is also important to consider the influence of non-human actors such as incompatible microcomputer systems, available software and professional development. 


\section{Background of the Authors}

Both of the authors completed university science degrees going on to become Secondary School Maths/Science teachers in the 1970s. Arthur Tatnall majored in physics at the University of Melbourne. This course contained one unit, in its third year, on computing that involved FORTRAN 4 programming using punched cards on an IBM mainframe. After completing the science degree and a Graduate Diploma in Education he then went on to become a school teacher and did not touch computing again until teaching at Watsonia High School in the mid-1970s. In the late 1970s he studies for a Graduate Diploma in Computer Science at Latrobe University. Bill Davey took a science degree majoring in pure and applied mathematics at Monash University and completed a unit of computing in that University - an important institution for the development of computing in the Australian context. He started teaching at Bendigo High School and undertook a post graduate computing course, at Bendigo Institute of Technology, that included languages such as FORTRAN, ALGOL and COBOL as well as data processing subjects. At the Bendigo High he taught programming to year 10 students in 1970, 1971 and 1972, initially using punched cards sent to Monash University and subsequently using punched cards run at the local Institute of Technology. Bill and Arthur met while teaching at Watsonia High, after which Bill became a member of the Mathematics Standing Committee for the Victorian Education Department at a time when the State Government was moving quickly to investigate the introduction of computers into schools. This put him at the centre of activities at the very start of the growth of educational computing in the State of Victoria.

\section{Schools in Victoria in the 1970s and 1980s}

The Commonwealth of Australia is a federation of six states and two territories each having a considerable degree of independence. Constitutionally, state governments have responsibility for school education, but in matters of perceived national importance the Commonwealth Government adopts a policy position and supplies funding for specific education projects (Tatnall, 1992). It is, nevertheless, the State Government Education Ministries that determine school curriculum, and how it is supported and delivered. In the 1970s and 1980s Arthur and Bill were both employed as secondary school teachers by the Victorian Ministry of Education.

In the 1970s and 1980s the State of Victoria had several different types of schools. Firstly there was the divide between Government and Non-Government (Independent) Schools with Non-Government schools making up around $30 \%$ of the total. As the name suggests, Government Schools were controlled directly by, and received their funding from the Victorian Ministry of Education. Their teachers were appointed, their conditions determined and their overall curriculum guidelines set by the Ministry. Non-Government schools were of two main types: Catholic Schools and Independent Schools. In each case these schools then received no funding from the State, but did receive some funding and support from the Commonwealth Government. They employed their own teachers and determined their own curriculum 
within broad guidelines laid down by the Victorian Ministry of Education (Tatnall \& Davey, 2008).

In the Government School sector students up to the age of about twelve attended Primary Schools and then moved to either High (Secondary) Schools or Technical Schools. The idea of dividing students into two streams for their post-primary education was to allow that some students were more academically inclined, while others needed a more practical education. In the late 1980s these two divisions were merged into what amounted to comprehensive Post-Primary schools. Administratively, each of these school types was attached to its own division within the Ministry of Education. These divisions were often non-cooperative, each pursuing their own policies and directions. This was in evidence in the Computer Education area, particularly in the often apparent friction between the Secondary and the Technical Divisions.

\section{School Computing Up to the Time of the Microcomputer}

Prior to the 1970s, for most people the idea of introducing school students to the use of computers, or of a school owing its own computer was difficult to imagine. School computing had begun in Victorian schools when a small number of minicomputers started to appear in the early 1970s (Tatnall, 1992; Tatnall \& Davey, 2004b). This typically resulted from the exposure of particular teachers to computing during their university studies. In 1972, for example, Burwood High School in Melbourne was loaned a PDP-8 computer by Digital Equipment (Salvas, 1985) and in 1973 McKinnon High School received a Government Innovations Grant to enable the purchase of an 8k Wang computer costing over \$10,000 (AUS) and requiring an annual maintenance contract of $15 \%$ of the purchase price. These early computers were typically used by school mathematics departments almost exclusively for the teaching of programming (Salvas, 1985) and so had very little overall impact on other aspects of education.

A bigger early impact on schools however, was the introduction of the Monash Educational Computer System (MONECS) making it possible for an average school to provide students with hands-on access to a computer before the PC became available. In 1974 a group at Monash University produced a system using mark-sense cards that allowed a class of 30 students to each get two runs in a one-hour period (Monash Computing Museum, 2003). The MONECS system was used to teach programming in FORTRAN or BASIC. At this stage schools saw computing as a branch of mathematics concerned with algorithm design (Tatnall, 2006; Tatnall \& Davey, 2004b) and the MONECS system provided a useful means of supporting this.

This situation began to change during the late 1970s and accelerated in the 1980s with the advent of the microcomputer. While microcomputers were much cheaper and more easily handled than minis and mainframes, in the late 1970s they were still quite foreign to most school teachers. In the late 1970s the number of microcomputers in Victorian schools began to grow rapidly but without any central direction from education authorities. In 1980 Anne McDougall was commissioned to report on how computers were then being used in schools and on the possibilities for their future use (McDougall, 1980). A few years later the use of Computers in Education in Schools 
began to be seen as an important national consideration and the Commonwealth Government noted the importance of introducing computers into schools. In 1973 the Commonwealth Schools Commission set up its National Advisory Committee on Computers in Schools (NACCS) to report on how it might help to provide funding for school computer education (Commonwealth Schools Commission, 1983; Tatnall \& Davey, 2008). In its report Teaching Learning and Computers in Schools (Commonwealth Schools Commission, 1983) the Committee made comprehensive recommendations covering curriculum development, professional development, support services, software/courseware, hardware and organisation. The report indicated that priorities for curriculum development should be:

- The provision of 'Computer Awareness' activities for all students in the earlier years of secondary schooling.

- The integration of computing into the school curriculum: 'computers across the curriculum'.

- Optional, in-depth Computer Studies courses at the secondary level.

- Curricula which met the special needs of relevant disadvantaged groups.

As the first priority in curriculum development, Computer Awareness courses around the country were given a considerable boost. In the period 1984-1986, the Commonwealth Government provided $\$ 19 \mathrm{~m}$ to support the program. One result of the Commonwealth involvement was funds to set up State Computer Education Centres in those states not already having them. These Centres aimed to provide both support and professional development to teachers involved in computer education.

\subsection{School Timetabling}

The energy around the concept of computers was evident in many ways. One example is the use that was made at Watsonia High School of the computing facilities at the nearby Latrobe University. Watsonia High had implemented a timetable that allowed students to study outside their age groups. The timetable was created from blocks of classes offered to students across multiple age levels. These blocks were created by first asking students what classes they would like to do, overlaying information from teachers as to ability groups and then maximising the number of choices from students within the blocks. This was a monumental mathematical task and was not helped by unstable teaching assignments (- teachers were often moved or promoted to another school during the summer break with little notice.) Latrobe University offered to help with the timetabling task and a computer program was written that significantly improved the whole process.

\subsection{The Teaching of Programming with Mark-Sense Cards}

Much of the computing that went on in classrooms before 1980 was justified as being part of a new approach to mathematics education. This manifested itself mostly in the teaching of computer programming. Programming was easy to justify, suited the largely mathematics teacher-base of enthusiasts at the time and could be implemented without the school needing to own a computer. Students could write programs and 
have them run asynchronously using any facilities available either at the school or in conjunction with a local university. This tradition started with the MONECS system but was quickly used in schools with microcomputers as cheap card-readers were available and a class of student programs could be batch processed and give every student something to do. The MONECS system used cards with removable chads, but card-readers using the simple expedient of two wires for each field, connected by the graphite trace of a mark sense card were readily available.

\subsection{The Acquisition of an Apple II at Watsonia High School}

In 1977 Watsonia High School, in the northern suburbs of Melbourne, obtained an Apple II microcomputer with $16 \mathrm{~Kb}$ RAM, a television monitor and a cassette tape drive as the result of a Curriculum Innovations grant submission to the Federal Government. As a member of the Secondary Mathematics Standing Committee, Bill had been encouraged to apply for this grant. The computer came with a number of pieces of software. The slightly later 'Apple Tapes Introductory Programs for the Apple ][ Plus' booklet (Apple Computer Inc., 1979) lists these as:

- Little Brick Out - an arcade game using the game controls

- Color Demosoft - a low resolution color programming demonstration

- Penny Arcade - an arcade game using the controls

- Lemonade - a business simulation asking you to manage a lemonade stand

- Hopalong Cassidy - a high resolution graphics game

- Phone List - an address book program using the cassette tape system for storage of up to 150 names and phone numbers

- Brian's Themes - high resolution Moire patterns demonstrating graphics programming

- Alignment Test Tone - a test tone to help align the read/write heads on your cassette tape recorder

- Renumber/Append - a programming utility to overcome the hassle of needing new line numbers in a BASIC program or the need to add some new lines to the end of a program

With such a 'plethora' of software it was possible to show other teachers just how useful (or otherwise) a computer could be. At Watsonia High this allowed a new Computer Awareness subject to be added to the year 10 curriculum (- this is discussed later). Of course, in practice, the programs were only ever used for demonstrating what might be possible and the computer was used mostly for programming classes until more computers became available at the school.

\section{Support from the Ministry of Education}

During the period 1978-1980 the discretionary fund of the Director of Secondary Education was used to support microcomputer purchase in a limited number of Victorian schools. The Director General's Computer Policy Sub-Committee also commissioned Anne McDougall, from Melbourne University Education Faculty, to 
undertake a study of the potential uses of computers in Victorian schools (Tatnall, 1992; Tatnall \& Davey, 2004b). Her report's recommendations (McDougall, 1980) included a major commitment to in-service education (professional development) of teachers, and suggested that adequate numbers of Computer Education Consultants should be made available to assist schools. The recommendations included support for the introduction of Computer Awareness and Computer Science courses, professional development for teachers, the standardisation of computer equipment, a resource library of computer education materials and the development of a range of courseware programs.

In 1978-1979 the Computer Policy Subcommittee of the Victorian Education Ministry Director General's Policy Committee produced a plan for the introduction of computers to schools. A key feature of the plan was that:

"There is an immediate need for post-primary divisions to appoint fulltime/part-time regional consultants for 1980 to establish clearing houses and assist in school program development and to co-ordinate the development of appropriate skills within each region" (Bainbridge, 1979).

The Computer Policy Sub-Committee agreed in the need to separate Computer Education from mathematics, and influenced the formation of three (divisional) Computer Education Curriculum Committees (Tatnall, 1992). After representations from one of the Regional Directors of Education and a group of Inspectors of Schools it also approved the appointment of three Computer Education Consultants with state-wide responsibilities. These (one year tenure) secondments were to commence in February 1980.

\subsection{The Computer Travelling Road Show}

In 1978 the Education Department's Secondary Mathematics Committee, after recognised the potential of computers in mathematics and other areas of education. set up its own 'Computer Education' subcommittee. Bill was appointed as a member of this subcommittee which then set up a 'Computer Travelling Road Show' which in 1979 commenced visits to schools around the State to promote the use of computers in mathematics education as well as in other subject areas. Members of the group, often including Bill, would travel in twos or threes, normally bringing a 16k Apple II microcomputer with cassette tape drive (on loan from Computerland in Sydney) to demonstrate computer applications involving graphics, mathematics, commerce and word processing (rather than just programming) to teachers at curriculum days and staff meetings.

A typical meeting with a school would involve the whole teaching staff of the school in a hall followed by demonstrations in the staff room. A mortgage calculator, lemonade and similar simulations were used to show the wide variety of potential applications possible with these simple machines. While some work was done with the mathematics departments on programming, this was generally due to the presence of a 'computer champion' in the school: a teacher with an interest in computing. The Road Show was almost always invited to schools by the School Principal or a member of the School Council. 
Of course 'little' details were glossed over in demonstrating to teachers the immense potential of general software in the classroom. These little details included:

- The need to constantly tune the tape recorder when transport caused the heads to move.

- The skill of being able to listen to the sound of the digital recording playing back through the speakers and to be able to align the tape so that the input of programs started with the program and not some hiss before the program.

- Being able to remember the machine code command in order to do soft reboots when the inevitable crash happened. Apple owners knew the operating system resided at memory location 3D0 and so knew that 3D0G would cause a restart.

- Since the monitor was just a TV set using the RF output from the computer a demonstrator needed to be able to handle interference, poor performance of the RF unit and normal TV maintenance.

- The expensive RAM chips (about $\$ 500$ for a 16k chip, or several weeks' pay for a teacher at the time) were seated in chip sockets that moved with heat, a demonstrator learned to wear a woollen jumper to polish the pins before reseating them after a hot session.

Of course these details were never part of the talks. In the very first years of use of the computer voice synthesis a version of voice recognition, graphics programs including simulations and such were all able to be shown. Some physics and chemistry teachers used the computer's games port to connect various scientific instruments, and all these applications became part of the show.

These Road Shows represented the Victorian Education Department's first official recognition of the importance of computers in education (Salvas, 1985; Tatnall, 1985).

\subsection{The Secondary Computer Education Committee}

In 1980, the Secondary Computer Education Curriculum Committee was formed with a membership made up of the original members of the Computer Education subcommittee of the Secondary Mathematics committee, several members of the Board of Inspectors of Secondary Schools, the three seconded computer consultants and a number of practising teachers (including Arthur). The brief of this committee was the production of Computer Awareness course guidelines, the investigation of Computer Science as a discipline, the publication of computer education articles, the collection and propagation of public domain software and the provision of in-service education (Tatnall, 1992).

\subsection{Computer Education Consultancy}

An important school curriculum support mechanism used by the Victorian Ministry of Education in the late 1970s and 1980s was the Regional Subject Consultant. This was a time of decentralisation and the Ministry had set up twelve Regional Offices around the state and in Melbourne, where many administrative matters were dealt with at a local level. The regions were not in any way really independent, but were used as a 
means of localising policies and decisions made by the Ministry of Education. An important function of the Regional Offices was to act as a base for the Regional Subject Consultants who spent much of their time serving the curriculum needs of local schools (Tatnall \& Davey, 2008).

The Consultants were practicing school teachers who were seconded from their schools, usually on a part-time basis, to work from their local Regional Education Office. They were chosen for their subject expertise, teaching ability, willingness to adapt to and lead educational change, and ability to get on with and work with other teachers. They were mostly subject specialists (in the case of secondary schools) and were appointed only for a period of twelve months at a time. The idea was that although they could be re-appointed for following years, they should not become permanent advisors who might then lose contact with the school classroom. Arthur and Bill were both part-time Computer Education Consultants in the early 1980s. Having to spend half of their time doing their normal teaching job in a school meant that there was little chance that a consultant could forget what it was like to be a classroom teacher! In the curriculum consultancy part of their job, however, consultants rarely had any interaction with school students, working instead with teachers and school principals. As some Commonwealth Government money went into funding the Regional Subject Consultants, although they themselves were Government School teachers their brief extended to servicing both Government and Non-Government schools.

Unlike most other subject consultants, Computer Education Consultants were pioneering a new area of education and had little in the way of established precedent, techniques or materials to assist them. A common starting point for teachers in thinking out how best to present subject matter to their students is to remember how they themselves were taught, but as the use of computers in education was an entirely new area and few teachers had any experience with it, most had little idea of where to begin. The task of the Computer Education consultants was thus to introduce, and offer suggestions on the use of computers in schools. Their work had various different forms including (Tatnall \& Davey, 2008):

- Professional Development activities run at the Regional Office and open to teachers from any school - often based around use of a particular software product.

- Professional Development activities within a given school that involved discussion of how some aspects of computing could be taught or how computers could be used in particular subject areas.

- Demonstration of educational software, and discussion of how it could be used in the classroom.

- Consultations with individual teachers on curriculum related matters.

- Investigation of possible school administrative uses of a computer.

- Individual consultations with school principals.

Consultancy was a very hectic life. Teachers considered the computing consultant to be their first port of call when computers broke down, when the Principal needed convincing, when classes required teaching ideas and when in-service education was required. In an era before mobile phones a day would start at the school or regional office answering machine significantly before school opening time. Calls that came in 
after hours would be returned to at least the school office (which opened early in most cases). A day would usually involve a morning and afternoon visit that had been preplanned and two or three emergency stops at schools where a problem could be solved with a known remedy or the dropping off of materials. Many evenings would see a school receiving either a general staff talk after classes had finished for the day or a meeting with the Ministry of Education or the Year 12 Computer Science group. To try to control this impossible workload several tactics were put in place at a very early stage. Teacher self-help groups (- VITTA and CEGV are mentioned elsewhere in this article) were created. Large and small conferences were used to try to create champions around the State. A typical small conference was held in July 1979. The day commenced with a panel discussion at 9:15am where 'experienced' teachers from the Northern Region detailed their use of computers. At 11:00 am a session of workshops was used to introduce new teachers to writing computer related activities into the general school curriculum. After lunch another workshop showed teachers how to use the available software to put these curriculum ideas into action. This conference involved 27 teachers representing 16 schools, and others were repeated all over the State.

In the mid-1980s several Regional Offices experimented with the concept of a General Curriculum Consultant, rather than Subject Consultants. These teachers were typically seconded full-time and were chosen for their broad view of the school curriculum. They would still do subject consultancy work, but would also work on other more general curriculum tasks. In 1983 and 1984 Arthur became a General Curriculum Consultant before moving on to a position at the State Computer Education Centre in 1985.

\subsection{Subject Teacher Associations and Conferences}

Several Subject Associations showed an early interest in the use of computers in schools, particularly the Mathematics, Science and Commercial Teachers' Associations. A new subject association: the Computer Education Group of Victoria (CEGV) was set up in the early 1980s. It is interesting to see that the names of a quite small number of individuals keep coming up in the history of educational computing in Victoria, often in connection with these subject associations.

\subsubsection{The Computer Education Group of Victoria (CEGV)}

The CEGV was formed in the late 1970s as an association of academics (mainly from education faculties), computer salespeople, some teachers and others interested in the use of computers in education. It came into prominence in 1979 when it launched the first Computer Education Conference in Australia. The CEGV, and its counterparts in other states, exerted a considerable influence on computer education through professional development activities, annual conferences, journals and the provision of other publications and resources. Both authors were members of the CEGV during this period and Arthur was elected CEGV President in the late 1980s. The CEGV ran a quite influential annual Computer Education conference during this period. In the mid-1980s, the various state Computer Education Groups formed the Australian Council for Computers in Education (ACCE) which then began to run an annual 
Australian Computers and Education Conference (which was held in a different State each year) and to lobby for computers in education at a federal level.

\subsubsection{Victorian Apple Computers in Education (VACE)}

Another type of group to emerge in the early 1980s was the 'user group'. In the early 1980s computer education had not progressed to the stage of being, to any degree, hardware independent. Schools using Apples had little to discuss with those using BBC, Cromenco or Commodore computers and their software and applications had too little in common. In September 1982 the authors, along with a secondary school principal, formed the Apple users group MACE (Melbourne Apple Computers in Education) which soon expanded its reach to the whole state and became VACE (Victorian Apple Computers in Education. These groups were formed at the grass roots by teachers to share knowledge between those using Apple II computers. From small beginnings VACE grew to have a membership in excess of 200 schools (Tatnall, 1985). Unlike the CEGV, VACE was very much a 'grass roots' organisation involving mainly practicing teachers. VACE conducted about two meetings per school term and fulfilled an in-service function. It had its own services section and software library and the VACE charter listed aims covering in-service education, helping with hardware problems and opportunities, software swapping, providing libraries of books and software and bulk buying schemes. The organisation was furiously busy for about 5 years then became irrelevant as the number of teachers with self-sufficient skills reached critical mass and hardware support ceased to a critical issue.

Although the Apple II was by far the most common computer used in secondary schools, the TRS-80, Acorn BBC computer, locally made Microbee and various 'industrial' computers used by Technical Schools were common enough to also need their own user groups. Many then delivered hours of useful in-service training and technical support. The importance of most of these groups sharply declined with the reduced emphasis on specific computer hardware of the later 1980s.

\subsubsection{The Victorian Information Technology Teachers Association (VITTA)}

In 1988 the Course Management Committee for HSC (Higher School Certificate) Computer Science (see later) saw a need for more support for teachers of the discipline of computing than was then available. In other subject areas teachers were principally supported by strong teacher subject associations, such as the Mathematics Association of Victoria, the Commercial Teachers Association of Victoria and so on. The much more general CEGV was so broadly based, covering teacher education and primary teaching so strongly that the specifics of computer science were largely neglected. On approach from the organisers of HSC Computer Science the CEGV agreed to call a meeting of Computer Science teachers at Melbourne High School. This was attended by teachers from all over the State and these people voted to create a new organisation dedicated to support of Computer Science teachers. The Victorian Information Technology Teachers Association (VITTA) was born from this meeting. (Bill and Arthur were leaders in this development). The aim of the organisation was to represent IT teachers at the various levels within the Education Ministry, to provide support materials for those preparing students for HSC Computer Science and the 
new VCE (Victorian Certificate of Education) ICT subjects (see later) and to provide general in-service education of teachers. A particular interest was to expose teachers to the industrial setting of computing through site visits. Many teachers could appreciate that much 'real computing' was done in a business setting, and that they themselves did not have sufficient knowledge of the way that business operates or what it does. The answer was to arrange a series of monthly meetings of VITTA, many of which would involve site visits. These meetings would typically begin at $7.30 \mathrm{pm}$ and go for 2 hours. The program of delivery of these visits for 1989 is instructive of the intentions of the group (Tatnall \& Davey, 1989):

- February - Kambrook factory to see how a modern factory operates with process-control technology and computer-assisted management.

- March - Discussion session of the new VCE Information Technology Field of Study, at Parade College. This focused closely on the 'Common Assessment Tasks' of the new course which were a range of assessment methods, all of which would be used to measure the progress of students in the new course.

- April - Hewlett Packard: 'Micros and Mainframes'. Tour of HP's Australian Headquarters and a series of talks on topics such as HP's New Wave software, RISC technology and computer peripherals.

- May - Ford Motor Company's Broadmeadows production line: 'Robots and Production'. Tour of the Ford plant with special attention to the use of robots for welding and sub-assembly. Comparison with the other 'human operated' parts of the production line. Discussion of the social issues of robots replacing workers, quality control with human workers vs. robots, boredom on a production line and training of workers.

- June - Space Time Research: Supermap CD. The use of compact disk optical storage technology.

Monthly meetings each attracted about 35 teachers for the first half of 1989 but by 1990 the group had grown in strength to provide a large stream in the annual conference of the CEGV. As VITTA became recognised, both officially by the Education Ministry and by the teachers of the new Information Technology subjects, another theme emerged from the massive restructure of the high school years dominated by University Entrance Examinations.

Over the decades form the 1950s to the 1990s university entrance had moved from domination by the universities to control by the Education Ministry. The controlling body moved through name and constitution from the Victorian Universities and Schools Examination Board, which set a curriculum and final examination for every subject recognised for university entrance through to (in 1989) the Victorian Curriculum and Assessment Board. By the end of the 1980s a different philosophy was guiding the final year curricula and issues such as gender equity and accessibility were seen as more important than entrance standards.

These forces culminated in a complete re-engineering of the curriculum of the final years of high school. The issue that affected VITTA was the demise of one area of study - Secretarial Studies. A whole cohort of teachers in schools had been devoted to the area to be scrapped by the new VCE. These teachers were typically members of the Victorian Commerce Teachers Association (VCTA), a large and powerful support 
group. This group intended to move their members from secretarial studies into the new information technology subjects (as both typewriters and computers had keyboards, and computers were used to replace what the typists previously taught). For a short time both VITTA and the VCTA provided support for teachers of the new subjects, but the VCTA soon found they had few resources and that teachers were deciding if their area was either commercial or computing. Senior members of the VCTA approached the leaders of VITTA offering support in the form of accommodation and administrative support if VITTA were to become jointly sponsored by the CEGV and the VCTA. This was agreed to and VITTA moved into the headquarters of the VCTA and proceeded to support both the outgoing Computer Science and Secretarial Studies Teachers as the new Information Technology subjects began in schools.

\subsubsection{The Australian Computer Society (ACS)}

The ACS is the organisation representing computer professionals in Australia and maintains an active interest in the use of computers in education. In the $1980 \mathrm{~s}$ it worked with the State Computer Education groups to achieve this end. Its direct influence at the school level was not large, but was significant particularly in the area of career education. Prominent ACS members frequently visited schools, on request, to speak to students about the computer industry and how computers were used in the business world. The ACS also ran an annual conference. In 1985 it ran the First Pan Pacific Computer Congress (PPCC) and Arthur Chaired its Schools Congress, attended by almost 1,000 students from Victorian schools. Arthur also chaired an ACS Schools Congress at the 1987 Australian Computer Conference.

\section{The Victorian State Computer Education Centre (SCEC)}

In Victorian schools, the early development of Computer Education was 'bottom up', beginning with the efforts of a small number of teachers and it took some time for the Education Department itself to become sufficiently interested to set up any form of central involvement. When the Computer Education explosion began in 1983 and the Education Department saw the need for some form of 'top down' planning and control, it became clear that there was a need for some central focus for computer education in the state. Policies of devolution and school-based decision making not-withstanding, in the early to mid-1980s the Education Department of Victoria still retained a quite strong central administration which facilitated the speedy and widespread adoption of computers in education while promoting a fairly common view of how computers could be used in education. There were, we believe, several key aspects of the computer education situation in Victoria that distinguished it from other curriculum areas, and that have benefited from a central operation. The first of these was the small number of people with expertise in the area: when a human resource is limited, it is a common response of any controlling group to centralise it, and this is what happened in the case of computer education (Tatnall, 1992).

Formation of the State Computer Education Centre (SCEC) of Victoria in 1984 was an important result. SCEC was set up in temporary premises at the old Moorabbin High School with 10 seconded staff, along with twelve Regional 
Computer Education Centres staffed by seconded teachers. In 1985, all positions were advertised and staffing at SCEC was formalised with the centre headed by the Senior Computer Education Officer with a Software Co-ordinator, Professional Development Co-ordinator, Curriculum Co-ordinator, Educational Computer Systems Analyst and Equal Opportunity Officer holding Vice-Principal Positions. Seventeen Senior Teacher positions (five at SCEC and twelve in the regions), and four Assistant Teacher positions made up a total staff of twenty-seven professional officers. Arthur Tatnall was appointed to the position of Educational Computer Systems Analyst at SCEC.

SCEC played a significant role in setting the direction of educational computing in Victoria for the next three years. It developed policy, produced curriculum documents, evaluated and distributed educational software, evaluated computer hardware and systems and produced the 'recommended list' of computer systems for use in schools, facilitated interstate contacts and the sharing of resources, conducted professional development activities, and generally co-ordinated computer education in the state.

\subsection{Recommendation of Computer Systems for Schools}

There was little software compatibility between the early types of PC used in schools and so it made a big difference to a school's computer education curriculum whether it used Apple //, BBC, Microbee, IBM or Macintosh computers (Tatnall \& Davey, 2004b). In every Australian state in the 1980s it was policy to recommend specific computer hardware for use in schools and so to comply with Government tender, offset and preferred supplier requirements. Government offset policy was designed to encourage local manufacture of computing equipment by requiring that foreign companies re-invest, in the state, $30 \%$ of the profits they made as the result of being nominated as a preferred supplier. The process of evaluating computing systems and recommending that preferred supplier status be conferred on a particular company is a task that needs to be done centrally. It would not be economically possible for such a function to be regionalised, let alone left to individual schools, and so it was a task performed by all State Computer Education Centres. This task alone could be used as a justification by Governments for setting up these Centres. One of the functions of the Victorian State Computer Education Centres was to control the proliferation of these brands by supporting only a limited number on a 'recommended list' so as to make realistic Education Department support possible. Evaluating computer systems and drawing up this list was Arthur's responsibility as Educational Computer Systems Analyst at SCEC.

\subsection{The Australian Educational Computer That Never Was}

Like several other countries (including the UK, New Zealand, Canada and Sweden), for both educational and industrial reasons Australia even commenced a project to design its own Australian Educational Computer (Tatnall, 1990), which fortunately (in retrospect) did not proceed past the design stage. Arthur had a direct involvement in much of this project as a member of the committee drawing up the Educational 
Technical Requirements (Tatnall, 2012 (forthcoming)). By the late-1980s the rise to dominance in schools of the IBM-compatible PC (MS-DOS and Windows) computer and the Apple Macintosh made this project unnecessary.

\section{Curriculum}

One of the early curriculum directions was 'computers across the curriculum' and Apple II software like: Lemonade, Hammurabi and the First Fleet (convict) database showed the possibilities here. Several streams of school computer education however, soon emerged:

\subsection{Programming in Mathematics Classes}

It is interesting that, while computing was often introduced to schools by a member of the school's mathematics department, computers per se quickly moved out of the mathematics curriculum (in favour of hand held electronic calculators). The introduction of Computer Science as a Matriculation (year 12) subject in 1981 was the death knell for computers in mathematics. This may be because of the prime place of mathematics as a prerequisite subject for science courses at universities. Teachers wanting their students to get the best possible university entrance score were reluctant to overload an already difficult mathematics curriculum with yet another topic. There had already been massive reforms involving set theory, known as 'The New Maths' and more change seemed like just too much. Eventually elaborate electronic calculators, capable of showing graphs, were used where a computer might have been relevant. Two very large projects did recommend the use of computers in mathematics. One was a complete overhaul of the mathematics curriculum expressed as a set of guidelines. The other was the Reality in Maths Education (RIME) project. In both cases computers were incorporated not as programming devices but as flexible means of displaying or calculating in other aspects of the curriculum and schools were given a very wide range of programs that could be run to demonstrate some mathematical concept more clearly on a computer screen. At the same time a significant number of teachers had been using LOGO to try to incorporate the ideas of Piaget and Papert into Mathematics classrooms, but these never became an official part of the mathematics curriculum of the State system.

\subsection{Computer Awareness}

Today there is no need to introduce secondary school students to computer technology, but in the early 1980s the situation was quite different. In Australia in the late 1970s and early 1980s considerable importance was put on the introduction of Computer Awareness courses in secondary schools when the first microcomputers started to appear. These courses were typically quite practical and involved a good deal of computer use rather than being wholly theoretical (Tatnall \& Davey, 2006, 2008). In Victoria in 1980 the McDougall report to the Education Department Computer Policy Committee noted that: 
"The case for computer education in schools is based largely on the need for children to be prepared for living in a society which is fast becoming dependant on the widespread application of computer technology.” (McDougall, 1980 :3)

It went on to suggest that:

"Computers have been called electronic 'brains' and there is no doubt that in the popular view, they are surrounded by an aura of mystery and are credited with powers they do not possess. The result is that most people outside the computing profession have attitudes of awe and fear towards computers and feel helpless and powerless in a highly computerised society." (McDougall, 1980 :3)

The report saw a need for computer education to begin by imparting an:

"informed understanding of the power and capabilities of computers and also of their limitations ... to every school pupil as part of a general education for modern living." (McDougall, 1980 :3).

The Secondary Computer Education Committee put an early priority on the introduction of Computer Awareness in the middle secondary school years and in 1980 proposed guidelines for a Year 10 Computer Awareness subject strongly stressing the interdisciplinary nature of this subject matter and that Computer Awareness should not be equated with Computer Programming. The Committee noted that although computers had become indispensable in the operations of science, business and government, they did not currently play a significant role in Victorian secondary education (Tatnall \& Davey, 2006). To justify the introduction of computers and related technology into the secondary school curriculum the Committee argued that as computers were beginning to exercise an important and growing influence on society, part of the school curriculum concerned with preparation for living in society should contain at least some elements of computer education (Secondary Computer Education Committee, 1980). The Committee's Year 10 curriculum guidelines noted that:

“... we define Computer Education in terms of computer 'awareness' the possession of skills and knowledge to enable informed judgments to be made on the basis of what is seen or heard about computers. ... the future citizen, ignorant of computers, will be functionally disadvantaged in a computer oriented society. In terms of 'social obligation' therefore, a strong case can be made for Computer Education. Since computers have significant social, political and economic consequences, an awareness of these consequences is essential to informed decision-making and to the democratic process." (Secondary Computer Education Committee, 1980 :1).

The document specified that such a course should have the following content (Secondary Computer Education Committee, 1980 :4-14):

- Section 1 ( $15 \%$ of available time):

i. Historical development of the computer: from the abacus, Pascal's adding machine, Babbage's Difference Engine and early electronic computers through to the microcomputer. 
ii. Structure of the computer: Analogue and digital computers. Input and output, processing, backing store.

- Section 2 (25\% of available time):

i. Hands-on experience in operating a microcomputer (booting the system, loading programs, running programs, creation and use of files, word processing, general computer usage).

ii. Algorithms - the concept of an algorithm, simple flowcharting.

iii. Elementary programming in BASIC.

- Section 3 (60\% of available time):

i. Use of computers in Government, industry/commerce, science/research, the arts, at home.

ii. Implications of computer use for society. Political, economic and social implications.

\subsubsection{A Computer Awareness Subject at Watsonia High School}

In 1979 Watsonia High introduced into the Year 10 curriculum what was to be one of the first Computer Awareness subjects introduced in Victoria. This was to be a core subject taken by all 150 Year 10 students at the school. The new subject came mainly from the initiative of a science teacher (Arthur Tatnall) who was then also a member of the Education Department's Secondary Computer Education Committee. The idea was for the subject to run for the whole year and consist of three parts, each of one term's duration delivered by a teacher who understood and could relate to this area (Tatnall \& Davey, 2004a). The teaching team consisted of this science teacher, a commerce teacher and a teacher of social science. Together they then set out to determine the requirements for the new subject which consisted of the following units:

- How a computer works, computer programming, history of computer technology.

- Business and commercial uses of information technology.

- The social implications of increased use of computers.

As secondary school curriculum in Victoria was school-based at this time and a matter to be determined by the whole teaching staff of the school, the next step was to convince the remainder of the teaching staff to vote for this change to the Year 10 curriculum, but given the interest in computers at the time convincing other teachers did not prove to be too difficult. In its first year, with only one microcomputer and some access to a mark-sense card system at a nearby university, the new subject involved a good deal more theory than practical use of computers. With additional hardware however, the subject became much more practical in subsequent years. It was immediately popular with the students, most of who were intrigued by the new computer. It was also seen as worthwhile by their parents, many of whom saw the possibility of better jobs for their children if they learned how to use these new machines. The subject remained in place at the school until the late 1980s by which time it had become redundant (Tatnall \& Davey, 2006). 


\subsection{Subject Use across the Curriculum}

Apart from general use in Primary Schools, many Secondary School teachers saw a place for computers in their own subject areas and a good deal of computer software was used in a wide range of subjects from History and English to Science and Secretarial Studies. As Computer Education Consultants, Bill and Arthur gave a good deal of attention to this topic in school visits.

In the mid-1980s a group within SCEC came to the view that the teaching of the discipline of computing in schools conflicted with the use of computers 'across the curriculum'. Their argument began with the view that since you did not need to know what was under the bonnet of a car in order to use a car, we should not be teaching students what goes on inside a computer as it was using computers that was all important. Arguments of equity were also raised. The counter argument was that it was important that Australian schools turn out students who were not just passive users of other people's technology and that future Australians should be able to understand the technology to the extent that they know its limitations and can adapt it to suit their own needs (Tatnall \& Davey, 1989).

\subsection{LOGO}

The 1981 conference of the CEGV involved Seymour Papert as keynote speaker. LOGO had been an integral part of computer education in Tasmania after its introduction by Scott Brownell in 1975 and the energetic work of Sandra Wills in transporting the equipment all around that State. Following Seymour Papert's use of a turtle in conjunction with Logo programming, in 1979 a Tasmanian company produced the Tasman Turtle, designed for use with Logo and an Apple II computer (Denning Branch International, 2009; Powerhouse Museum, 2012). This proved popular both in making programming in Logo more concrete and as a demonstration of the power of robotics (Tatnall \& Tatnall, 1987). Later a connection was established between Lego and Logo (Carter, 1988). A committed group in Victoria produced versions to run on the common microcomputers available, wrote books expanding on the possibilities and educational theory and generally served as missionaries for LOGO (Jones, McDougall, \& Murnane, 2004). Logo was used at all school levels and in articles for the 1983 Australian Computers in Education Conference, Terry Malone discusses using Logo in Primary Schools (Malone, 1983) while Anne McDougall and Tony Adams advocated its use with senior secondary school students (McDougall \& Adam, 1983). In the proceedings of the 1986 conference Tony Gilding and Jon Pearce investigate use of Logo to teach science concepts (Gilding \& Pearce, 1986) and Chris Bigum offers some critical reflections (Bigum, 1986). Following the turtle, Logo was also used with robotics and control technology (Tatnall \& Davey, 1986; Tatnall \& Tatnall, 1987)

\subsection{Computer Science (Higher School Certificate)}

In 1981, as a result of many years of effort by a group university academics, Computer Science was first offered as a Higher School Certificate (HSC, Year 12) subject in Victoria, although personnel from the Education Department had little 
involvement in determining the nature and content of this subject. The public: parents, students and employers readily accepted HSC Computer Science and student numbers increased rapidly. In its first year 120 students from 10 schools studied Computer Science, but this number increased by over $50 \%$ in each of the next five years before making a slower increase to over 2200 in 1991 with virtually every secondary school in the state offering the subject.

The content of this subject included the following topics: computer structure and data representation, algorithms and modelling, programming languages, data structures, input/output devices, file structures, system software, and social implications (Victorian Institute for Secondary Education, 1984). In addition, students undertook one of the following two optional units: computers in science and engineering, or computers in business and government. Practical work was seen as an important part of the course. Arthur and Bill were both members of the HSC Computer Science Subject Committee and Computer Science examiners, and Arthur later became Chief Examiner in HSC Computer Science.

Not all teachers, however, were in favour of the new subject and from the mid1980s when Computer Science was still in a rapid growth phase a number began to question its place. Their arguments had several stands: firstly some claimed that Computer Science was an elitist academic subject and was too difficult for some students and so should not be supported. Others noted that the ratio of girls to boys taking Computer Science was almost as low as that for physics and expressed concern that it was becoming a boys' subject, a concern which the subject committee shared and tried to address. Perhaps, however, the most damaging criticism came from those teachers who claimed that the presence of a specialist subject detracted from the move to encourage the use of computers across the curriculum as the demands made on school computing facilities by Computer Science classes made it difficult for others to obtain adequate access to the machines. They saw Computer Science and computers across the curriculum as adversaries and it took some time before they could be convinced that a school was more likely to have a large number of computers if it offered Computer Science, and these points of view were reconciled.

One of the curriculum offerings in Victorian Technical Schools was Year 11 Computer Studies (McCluskey, Adair, Feil, \& Smulders, 1983), but this was taught rather differently than similar named subjects in High Schools as Technical School courses were rather more related to business training and employment than those in the High Schools. The Technical Division expressed a need for their schools to use 'industry standard' hardware and software with microcomputers based on the Z80 chip running the $\mathrm{CP} / \mathrm{M}$ operating system (such as the Cromenco, Micromation and Pulsar) and business software such as WordStar and dBASE. Later, when the IBM PC appeared, there was a move to MS-DOS in these schools.

\subsection{Information Technology Studies - VCE}

In 1992 HSC Computer Science was replaced by the more general subject area 'Information Technology' as part of the newly introduced Victorian Certificate of Education (VCE). At this time several subjects had been made redundant as they were seen as having died due to a perceived lack of interest. A particular case was Secretarial Studies which had occupied a comfortable niche as a vocational subject 
preparing (mainly) girls for entry into office and administrative jobs. The idea of teaching typing on typewriters was, however, now seen as anachronistic and the numerically large and influential group of Secretarial Studies teachers made redundant in this process produced a powerful pressure group which was influential in the development of new computing subjects (Tatnall \& Davey, 2010), particularly as they might relate to word processing.

Computer Science was replaced with three Year 12 subjects: Information Processing and Management, Information Systems and Information Technology in Society. Each of these subjects comprised two units. An additional new subject: Information Technology was offered only at Year 11. The group designing these new subjects aimed to provide a new subject area with a much wider appeal. Bill was a member of this group.

\section{Textbooks}

By 1984 Computer Science had overcome the main problems of acceptance as a 'real' subject, mostly in that it was now able to contribute to a score for the competitive university entrance process. The growing number of students aroused the interest of all text book publishers and an Australian publisher approached us to provide for the largest market segment - year 11 students. The first text produced was indicative of the climate at this time: Computer Science for Year 11 (Tatnall \& Davey, 1985). The text was clearly aimed at preparing students for the year 12 Computer Science subject and it quickly became the top selling text for year 11 students in Victoria as it had been produced by two practicing teachers who were also part of the central process of curriculum development. By 1990 the climate had changed and our next text was called Information Technology Studies (Tatnall \& Davey, 1990), a reflection of the move away from the more technical name 'Computer Science' and reflecting the advancing values of those who wanted to make computing in schools available to all. One of the largest selling text for computing at year 12 by 1991 had the revealing title: Information Technology: Theory, Application and Impact (Woodhouse \& Tatnall, 1991)

\section{Conclusion}

Computer education became a mainstream activity in Victorian schools in a period of less than ten years from the late 1970s to the late 1980s. This adoption reflected a climate of intense enthusiasm and vision for the microcomputer, and of the success of attempts to support and train teachers in a completely new area. Factors in this success were:

- the Travelling Computer Road Show,

- the State Computer Education Centre,

- Computer Subject Associations, and in particular

- the Computer Education Consultants. 
These Consultants were taken from the classroom on the basis of their expertise and enthusiasm so that they could help their colleagues by using their full knowledge of the working conditions in schools. They were also extended trust by the people they helped as they came from the same background. The measure of their success is the speed with which they did away with the need for their services.

Those of us involved at the beginning of the Computer Education revolution in Australia had great hopes that the introduction of computers would make a profound difference, and significantly improve the quality of school education. In the late 1980s Arthur and Bill each moved into university Departments of Information Systems and largely out of school computing, bring to an end this history of computers in schools. A lot happened in school computing in the 1990s and 2000s, particularly with the use of the Internet, but that is not a part of our story.

\section{References}

Apple Computer Inc., The Apple Tapes Introductory Programs for the Apple ][ Plus: Apple Computer Inc. (1979)

Bainbridge, W.J.: Internal memo to all policy committees (November 1979)

Bigum, C.: Logo, Some Critical Reflections. Paper Presented at the Australian Computer Education Conference - Computers in Education: On the Crest of a Wave, Melbourne (1986)

Callon, M.: Some Elements of a Sociology of Translation: Domestication of the Scallops and the Fishermen of St Brieuc Bay. In: Power, Action \& Belief. A New Sociology of Knowledge?, pp. 196-229. Routledge \& Kegan Paul, J. Law. London (1986)

Carter, P.: Lego and Logo: the Bits Between. Paper Presented at the Australian Computer Education Conference - Golden Opportunities, Adelaide (1988)

Commonwealth Schools Commission, Teaching, Learning and Computers. Report of the National Advisory Committee on Computers in Schools. Commonwealth Schools Commission, Canberra (1983)

Denning Branch International (2009). The Old Robots Web Site - the First Wave of RoboticsRetrieved (May 2012),

http: / /www. theoldrobots.com/turtle1.html

Gilding, A., Pearce, J.: Logo and the Exploration of Some Concepts in Science. Paper Presented at the Australian Computer Education Conference - Computers in Education: On the Crest of a Wave, Melbourne (1986)

Jones, A., McDougall, A., Murnane, J.: What did we think we were doing? In: Impagliazzo, J., Lee, J.A.N. (eds.) History of Computing in Education, pp. 83-90. Kluwer Academic Publishers/IFIP, Assinippi Park, Massachusetts (2004)

Latour, B.: Technology is society made durable. In: A Sociology of Monsters. Essays on Power, Technology and Domination. Routledge, J. Law. London (1991)

Latour, B.: Aramis or the Love of Technology. Harvard University Press, Cambridge (1996)

Malone, T.: Strategies for Using Logo in the Classroom. Paper Presented at the Australian Computer Education Conference - Could You Use a Computer?, Melbourne (1983) 
McCluskey, D., Adair, I., Feil, C., Smulders, M.: Teaching Year 11 Computer Studies. Paper Presented at the Australian Computer Education Conference - Could You Use a Computer?, Melbourne (1983)

McDougall, A.: Computers and Post-Primary Education in Victoria: a Study of Needs. Education Department of Victoria, Computer Policy Committee, Melbourne (1980)

McDougall, A., Adam, T.: Logo for Senior Secondary School Students. Paper Presented at the Australian Computer Education Conference - Could You Use a Computer?, Melbourne (1983)

Monash Computing Museum. MONECS Deamon Educational Computer system (2003), http: / /www. csse.monash. edu. au/museum/ (retrieved February 2004)

Powerhouse Museum, Powerhouse Museum Collection Search - Tasman Turtle (2012), http: / / www . powerhousemuseum. com/collection/database / ? irn=262955 (retrieved May 2012)

Salvas, A.D.: Personal communication (1985)

Secondary Computer Education Committee, Year 10 Computer Education: Guidelines for Secondary Schools. Education Department of Victoria, Melbourne (1980)

Tatnall, A.: The Role of the State Computer Education Centre of Victoria, Minor. Deakin University, Geelong (1985)

Tatnall, A.: Designing the Australian Educational Computer. Education 110(4), 453-456 (1990)

Tatnall, A.: The Growth of Educational Computing in Australia. In: Goodson, I.F., Mangan, J.M. (eds.) History, Context, and Qualitative Methods in the Study of Education, London, Ontario, vol. 3, pp. 207-248. University of Western Ontario, Canada (1992)

Tatnall, A.: Curriculum Cycles in the History of Information Systems in Australia. Heidelberg Press, Melbourne (2006)

Tatnall, A.: The Australian Educational Computer That Never Was. IEEE-Annals of the History of Computing (forthcoming, 2012)

Tatnall, A., Davey, W.: Computer Science for Year 11. Jacaranda Press, Brisbane (1985)

Tatnall, A., Davey, W.: Conceptual Development Through Robotics: Information Technology in Practice. Paper Presented at the Australian Computer Education Conference - Computers in Education: On the Crest of a Wave, Melbourne (1986)

Tatnall, A., Davey, W.: Making Information Technology Real. Paper Presented at the ACEC 1989, Backup the Future, Canberra (1989)

Tatnall, A., Davey, W.: Computer Science for Year 11: Information Technology Studies. The Jacaranda Press, Milton (1990)

Tatnall, A., Davey, W.: Improving the Chances of Getting your IT Curriculum Innovation Successfully Adopted by the Application of an Ecological Approach to Innovation. Informing Science 7(1), 87-103 (2004a)

Tatnall, A., Davey, W.: Streams in the History of Computer Education in Australia. In: Impagliazzo, J., Lee, J.A.N. (eds.) History of Computing in Education, pp. 83-90. Kluwer Academic Publishers/IFIP, Assinippi Park, Massachusetts (2004b)

Tatnall, A., Davey, W.: Early Computer Awareness Courses in Australian Secondary Schools: Curricula from the late 1970s and early 1980s. In: Impagliazzo, J. (ed.) History of Computing and Education 2, pp. 107-116. Springer, New York (2006)

Tatnall, A., Davey, W.: Computer Education Support Structures in Victorian Schools in the 1980s. In: Impagliazzo, J. (ed.) History of Computing and Education 3, pp. 1-22. Springer, New York (2008) 
Tatnall, A., Davey, B.: The Life and Growth of Year 12 Computing in Victoria: An Ecological Model. In: Tatnall, A. (ed.) HC 2010. IFIP AICT, vol.325, pp. 124-133. Springer, Heidelberg (2010)

Tatnall, A., Tatnall, B.: Logo in Control: Control Technology in Education. Paper Presented at the Australian Computer Education Conference - Tomorrow's Technology Today, Adelaide (1987)

Victorian Institute for Secondary Education, Handbook for, Year 12 Curriculum and Assessment. Victorian Institute for Secondary Education, Melbourne (1984)

Woodhouse, D., Tatnall, A.: Information Technology: Theory, Application and Impact. Dellasta, Melbourne (1991) 